\title{
SISTEM CERDAS MONITORING KEHADIRAN GURU DAN SISWA DENGAN APLIKASI TELEGRAM BERBASIS WEB RESPONSIVE PADA SMP NEGERI 16 BULUKUMBA
}

\author{
Butsiarah $^{1}$, Markani ${ }^{2}$ \\ ${ }^{1}$ Teknik Informatika, STMIK AKBA, Makassar, Indonesia \\ ${ }^{2}$ Sistem Informasi, STMIK AKBA, Makassar, Indonesia \\ 'butsiarah@akba.ac.id, ${ }^{2}$ markani@akba.ac.id
}

\begin{abstract}
ABSTRAK
Informasi kehadiran guru dan siswa sangat diperlukan untuk pengolahan data dan pelaporan kehadiran kepada pihak yang membutuhkan. Namun. Misalnya ketika orang tua siswa membutuhkan informasi kehadiran anaknya disekolah dalam mengikuti mata pelajaran. Begitupun dengan kepala sekolah untuk mendapatkan informasi kehadiran guru mata pelajaran. Berdasarkan masalah tersebut dirancang sistem cerdas monitoring kehadiran guru dan siswa secara real time melalui aplikasi telegram kepada pihak-pihak yang membutuhkan informasi tersebut. Sistem cerdas ini bekerja secara real time dalam memberikan informasi kehadiran guru dan siswa. Orang tua siswa mendapatakn informasi kehadiran anaknya secara real time pada setiap mata pelajaran melalui aplikasi telegram tanpa harus dating ke sekolah demi mendapatkan informasi tersebut. Begitupun dengan kepala sekolah dapat memonitoring kehadiran guru mata pelajaran secara real time melalui aplikasi telegram, selain itu kepala sekolah juga dapat memilhat laporan kehadiran guru pada sistem cerdas tersebut tanpa meminta informasi lagi ke staft tata usaha. selain itu guru bimbingan konseling (BK) dan wali kelas juga dapat memonitoring kehadiran siswa. System cerdasar ini dibuat dengan menggunakan model pengembangan sistem yaitu Rapid Aplication Depelopment (RAD) dengan menggunakan tools perancangan system Unified Modelling Language (UML) yang terdiri atas Use Case Diagram, Class Diagram, Activity Diagram dam Sequence Diagram. Dalam pembuatan sistem ini menggunakan bahasa pemrograman html dan php dengan database mysql. Berdasarkan hasil pengujian sistem yang telah dilakukan kepada responden, maka sistem cerdas monitoring kehadiran guru dan siswa dengan aplikasi telegram berbasis web responsive pada SMP Negeri 16 Bulukumba dinyatakan layak dengan persentase kelayakan sebesar $93 \%$.
\end{abstract}

Kata Kunci - Sistem Cerdas, Monitoring Kehadiran, Aplikasi Telegram, Web Responsive.

\begin{abstract}
Teacher and student attendance information is needed for data processing and attendance reporting to those who need it. However. For example, when parents of students need information on their children's attendance at school in following subjects. Likewise with the principal to get information on the attendance of subject teachers. Based on this problem, a smart system for monitoring the presence of teachers and students in real time is designed via the telegram application to those who need this information. This smart system works in real time to provide teacher and student attendance information. Parents of students get real-time attendance information on each subject via the telegram application without having to come to school to get this information. Likewise, the principal can monitor the attendance of subject teachers in real time through the telegram application, besides that the principal can also see the teacher attendance report on the smart system without asking for more information from the administrative staff. Besides that, the counseling guidance teacher $(B K)$ and the homeroom teacher can also monitor student attendance. This intelligent system is made using a system development model, namely the Rapid Application Depelopment (RAD) using the Unified Modeling Language (UML) system design tools consisting of Use Case Diagrams, Class Diagrams, Activity Diagrams and Sequence Diagrams. In making this system using the programming language html and php with the mysql database. Based on the results of system testing that has been carried out on respondents, the intelligent system of monitoring teacher and student attendance with a responsive web-based telegram application at SMP Negeri 16 Bulukumba is declared feasible with an eligibility percentage of $93 \%$.
\end{abstract}

Keywords - Smart System, Attendance Monitoring, Telegram Application, Responsive Web. 
Universitas AL Asyariah Mandar

\section{PENDAHULUAN}

Pemanfaatan teknologi informasi sangat diperlukan untuk memberikan kemudahan dalam melakukan aktifitasaktifitas manusia, contohnya dalam pendataan administasi kehadiran karyawan, mahasiswa maupun siswa yang berbasis database. Pengelolaan adminsitrasi kehadiran akan membutuhkan waktu yang sangat lama jika masih dilakukan secara manual karena harus dilakukan pengecekan satu persatu daftar hadir yang sudah diisi. Namun, hal ini dapat diminimalisir dengan membuat sebuah sistem cerdas yang dapat secara langsung memberikan informasi kehadiran yang dibutuhkan secara real time yang dapat diakses kapanpun dan dimanapun dengan pemanfaatan aplikasi media sosial telegram. Sistem monitoring kehadiran Guru dan Siswa adalah suatu proses pengawasan yang dilakukan oleh pihak-pihak tertentu baik secara offline maupun online dengan tujuan proses pendataan kehadiran Guru dan Siswa dapat berjalan dengan optimal. Pihak-pihak tertentu tersebut yaitu Wali Kelas, Guru BK, Orang Tua/Wali dan kepala sekolah untuk mengetahui kehadiran mengajar guru mata pelajaran. Namun, Pengawasan secara offline (manual) kurang efektif dan akurat karena data dapat dimanipulasi, misalnya siswa tidak terekam atau tersimpan otomatis kedalam sebuah database dan informasi yang dibutuhkan oleh orang tua siswa tentang kehadiran anaknya tidak up to date (real time). Berdasarkan permasalahan tersebut, maka peneliti membangun suatu sistem cerdas monitoring kehadiran Guru dan Siswa dengan aplikasi telegram berbasis web responsive dengan tujuan agar data administrasi kehadiran Guru dan Siswa pada SMP Negeri 16 Bulukumba bisa dikelola secara optimal serta dapat menjadi kontribusi positif bagi peneliti demi pengembangan kedepannya dalam pemanfaatan teknologi informasi untuk bisa bersaing dengan sekolah-sekolah lain dalam bidang IT dalam peningkatan kinerja SMP Negeri 16 Bulukumba.

\section{TINJAUAN PUSTAKA}

\subsection{Analisi Sistem}

Analisis adalah suatu proses yang dilakukan untuk mengidentifikasi kelebihan dan kekurangan dari suatu objek tertentu. Sedangkan sistem adalah kumpulan dari bagian-bagian (elemen-elemen) dari objek yang saling berinteraksi untuk bekerjasama dalam mencapai suatu tujuan. Jadi analisis sistem adalah proses yang dilakukan untuk menguraikan bagian-bagian dari sistem yang sedang berjalan untuk mengidentifikasi dan mengevaluasi permasalahan, kesempatan, hambatan yang terjadi dan kebutuhan yang diharapkan sehingga dapat diusulkan perbaikan.

Analisis sistem dilakukan dengan alasan yaitu :

2.1.1. Problem-solving, sistem lama tidak berfungsi sesuai dengan kebutuhan. Untuk itu analisis diperlukan untuk memperbaiki sistem sehingga dapat berfungsi sesuai dengan kebutuhan.

2.1.2. Kebutuhan baru, adanya kebutuhan baru dalam organisasi atau lingkungan sehingga diperlukan adanya modifikasi atau tambahan sistem informasi untuk mendukung organisasi.

2.1.3. Mengimplementasikan ide atau teknologi baru.

2.1.4. Meningkatkan performansi sistem secara keseluruhan

\subsection{Perancangan Sistem}

Perancangan adalah suatu fase dimana diperlukan suatu keahlian perencanaan untuk elemen-elemen komputer yang akan menggunakan sistem baru. Ada dua hal yang perlu diperhatikan dalam perancangan sistem yaitu pemilihan peralatan dan program komputer untuk sistem yang baru. Ada beberapa alat bantu yang digunakan dalam perancangan sistem yaitu Unified Modeling Language (UML). (Kristanto, 2004:65).

a. Use Case Diagram

Use case diagram menggambarkan fungsionalitas yang diharapkan dari sebuah sistem. Yang ditekankan adalah "apa" yang diperbuat sistem, dan bukan "bagaimana". Sebuah use case merepresentasikan sebuah interaksi antara aktor dengan sistem. Use case merupakan sebuah pekerjaan tertentu, misalnya login ke sistem, meng-create sebuah daftar belanja, dan sebagainya. Seorang/sebuah aktor adalah sebuah entitas manusia atau mesin yang berinteraksi dengan sistem untuk melakukan pekerjaanpekerjaan tertentu.

b. Sequence Diagram

Suatu sequence diagram adalah suatu diagram interaksi yang menekankan pada pengaturan waktu dari pesan-pesan. Diagram ini menampilkan sekumpulan peran dan pesanpesan yang dikirim dan diterima oleh instansi yang memegang peranan tersebut. Sequence diagram menangkap objek dan class yang terlibat dalam skenario dan urut-urutan pesan yang ditukar antara objek diperlukan untuk melaksanakan fungsionalitas skenario. Booch (2005).

c. Class Diagram

Class diagram menunjukan sekumpulan kelas, antarmuka, dan kerjasama serta hubungannya. Class diagram digunakan untuk memodelkan perancangan statik dari gambaran sistem. Biasanya meliputi permodelan vocabulary dari sistem, permodelan kerjasama, atau permodelan skema. Booch (2005).

\subsection{Model Pengembangan Sistem}

Model pengembangan sistem yang akan peneliti gunakan dalam membangun sistem monitoring kehadiran guru dan siswa adalah Rapid Aplication Depelopment (RAD) karena RAD memiliki siklus pengembangan yang cepat, pendek dan singkat. Terdapat tiga fase dalam RAD yang melibatkan penganalisis dan pengguna dalam tahap penilaian, perancangan, dan penerapan. Adapun ketiga fase tersebut adalah :

a. Requirements planning (perencanaan syarat-syarat)

b. RAD design workshop (workshop desain RAD)

Implementation (implementasi)

2.4. Bahasa Pemrograman PHP 
PHP merupakan bahasa pemrograman web-server-side, script yang membuat dokumen HTML secara on the fly, yaitu dokumen HTML yang dihasilkan hanya pada saat diakses oleh user. Sehingga suatu halaman HTML tidak lagi bersifat statis, namun menjadi bersifat dinamis. Sifat serverside ini membuat pengerjaan script tersebut dikerjakan di server sedangkan yang dikirim kepada browser adalah hasil proses dari script tersebut sudah berbentuk HTML. Karena PHP merupakan server-side scripting maka PHP dapat melakukan pengumpulan form data, men-generate dynamic page content atau mengirim dan menerima cookies, dan juga banyak fungsi yang lain. Untuk dapat menjalankan fungsi sebagai server-side scripting maka dibutuhkan PHP parser, webserver, dan webbrowser. Webbrowser perlu dijalankan dan digabungkan dengan instalasi PHP. Untuk mengakses PHP, dapat digunakan web browser yang dapat melihat hasil dari script PHP.

2.5. Database Mysql

MySQL adalah sebuah aplikasi Relational Database Management Server (RDBMS) yang sangat cepat dan kokoh. Dengan menggunakan MySQL Server maka data dapat diakses oleh banyak pemakai secara bersamaan sekaligus dapat membatasi akses para pemakai berdasarkan privilege (hak akses) yang diberikan. MySQL menggunakan bahasa SQL (Structured Query Language) yaitu bahasa standar yang digunakan untuk pemrograman database. MySQL sekarang tersedia dibawah izin open source, tetapi juga ada izin untuk penggunaan secara komersial. Keunggulan dari MySQL adalah:

a. Bersifat open source.

b. Sistem yang digunakan oleh perangkat lunak ini tidak memberatkan kerja dari server, karena dapat bekerja di background.

c. Mempunyai koneksi yang stabil dan kecepatan yang tinggi.

2.6. Aplikasi Telegram

Telegram adalah aplikasi gratis dan akan terus gratis, tidak akan pernah ada iklan atau biaya lain untuk selamanya. Banyak pengguna yang merasakan jika mengirim pesan via Telegram lebih cepat dibandingkan WhatsApp karena Telegram berbasis cloud. Ukuran aplikasi yang lebih kecil membuat telegram lebih mudah dijalankan. Telegram versi 3.8.1 pada iPhone yang dikeluarkan pada 28 April 2016 memiliki ukuran 33.1 MB. Sedangkan Telegram yang merupakan aplikasi messenger berbasis cloud mempunyai proses sinkronisasi yang mulus. Apabila pengguna sedang menggunakan komputer atau laptop, aplikasi Telegram pada telepon genggam tak perlu aktif sehingga lebih menghemat baterai. Fitur Bot adalah akun yang dijalankan oleh aplikasi (bukan) orang. Bot ini dilengkapi fitur AL (Artificial Intellegence-kecerdasan buatan). Bot dapat melakukan apa saja seperti game, broadcasting dan apa saja aktivitas di internet.

Berdasarkan alasan tersebut, maka peneliti memilih aplikasi telegram untuk peengiriman informasi berbasis real time karena penggunaan smarphone android saat ini telah banyak digunakan khususnya pada lingkungan pada objek penelitian para orang tua/wali siswa

\section{METODE}

\subsection{Analisis}

Penelitian ini dilakukan dengan pendekatan kualitatif. Studi kasus dilakukan pada proses pembelajaran selama satu semester terakhir yaitu tahun pelajaran 2019/2020 genap di SMP Negeri 16 Bulukumba agar data-data yang diperoleh lebih akurat (terpercaya) dengan tujuan menghasilkan sistem cerdas monitoring kehadiran Guru dan Siswa melalui aplikasi telegram berbasis web responsive yang multi user. Metode pengembangan sistem yang digunakan pada penelitian ini adalah model Rapid Aplication Depelopment (RAD) karena memiliki sisklus pengembangan yang pendek, singkat dan cepat yang memiliki 3 (tiga) fase (tahapan) yaitu :

a. Requirements Planning (Perencanaan Syarat-Syarat) Pada tahapan ini peneliti melakukan pengamatan langsung terhadap objek penelitian tentang permasalahan yang dialami pengguna. Wali/Orang tua siswa harus datang ke sekolah untuk menanyakan kehadiran anaknya pada setiap mata pelajaran yang telah diikuti. Peneliti juga melakukan wawancara kepada salah seorang guru mata pelajaran terkait cara kepala sekolah dalam memonitoring kehadiran guru mata pelajaran setiap pergantian jam mata pelajaran. Dengan adanya permasalahan tersebut, maka peneliti pengusulkan untuk membangun sistem monitoring kehadiran guru dan siswa secara real time untuk memberikan kemudahan dalam memperoleh informasi khususnya kehadiran guru dan siswa. Selain itu, dapat mempermudah bagian tata usaha, guru bimbingan konseling dan wali kelas dalam pengarsipan data-data kehadiran guru dan siswa.

b. RAD Design Workshop (Workshop Desain RAD) Pada tahapan ini dilakukan proses perancangan sistem monitoring kehadiran guru dan siswa melalui aplikasi telegram berbasis web responsive. Perancangan ini dilakukan dengan menggunakan salah satu tools perancangan Unifeid Modelling Languge (UML). Jenis diagram UML yang digunakan diantaranya adalah use case diagram, sequence diagram dan class diagram. Pada proses perancangan peneliti dan anggota peneliti intens melakukan komunikasi dengan pihak sekolah melalui media sosial terkait permasalahan yang dialami oleh pengguna.

c. Implementation (Implementasi)

Pada tahapan dilakukan pembuatan sistem oleh programmer. Setelah sistem selesai maka tahapan uji coba akan dilakukan dengan meminta masukan dari pengguna apabila ada perbaikan. Setelah tahapan uji coba selesai, maka langkah selanjutnya adalah memperkenalkan sistem kepada pihak sekolah secara umum untuk dapat digunakan bersama. Adapun diagram alir penelitian sistem cerdas monitoring Kehadiran Guru dan Siswa dengan Aplikasi Telegram Berbasis Web Responsive pada SMP Negeri 16 Bulukumba sebagai berikut : 


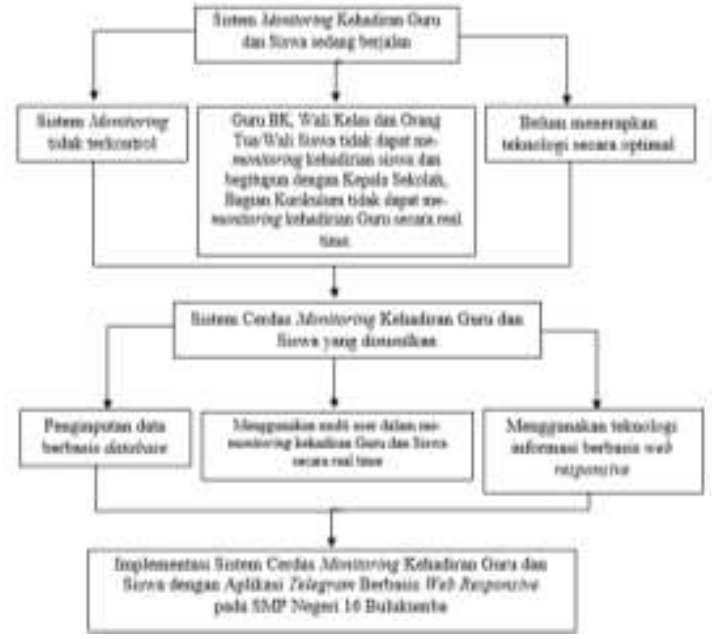

Gambar 3.1. Diagram Alir Penelitian

3.2. Peracangan Pemodelan Sistem

\section{a. Use Case Diagram}

Use Case diagram menjelaskan fungsi dari setiap actor atau pengguna yang terlibat dalam sistem tersebut, seperti terlihat pada gambar 3.2.

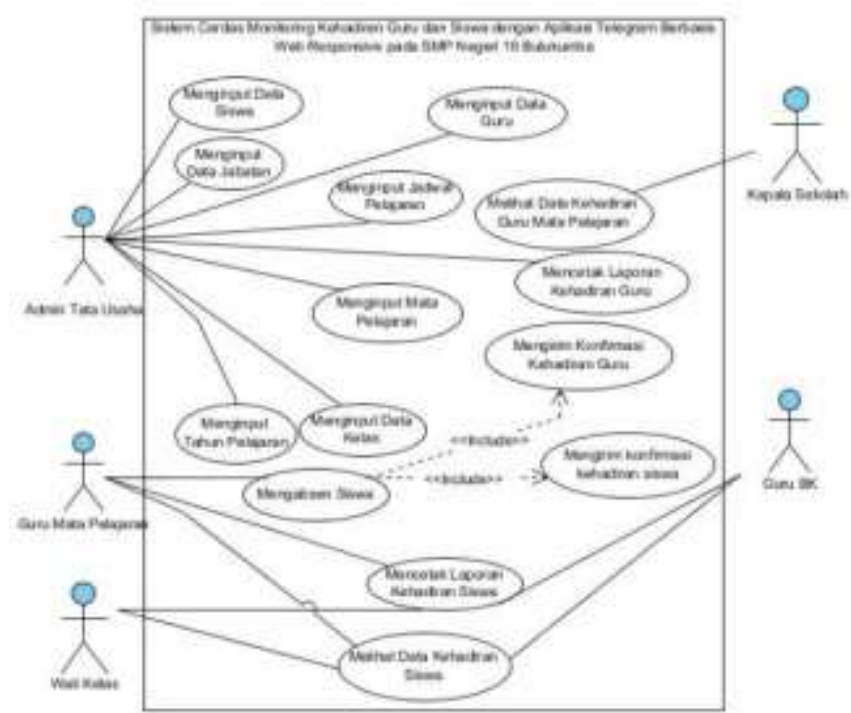

Gambar 3.2. Use Case Diagram Sistem cerdas monitoring kehadiran guru dan siswa dengan aplikasi telegram berbasis web responsive pada SMP Negeri 16 Bulukumba b. Activity Diagram

1). Input Data Guru

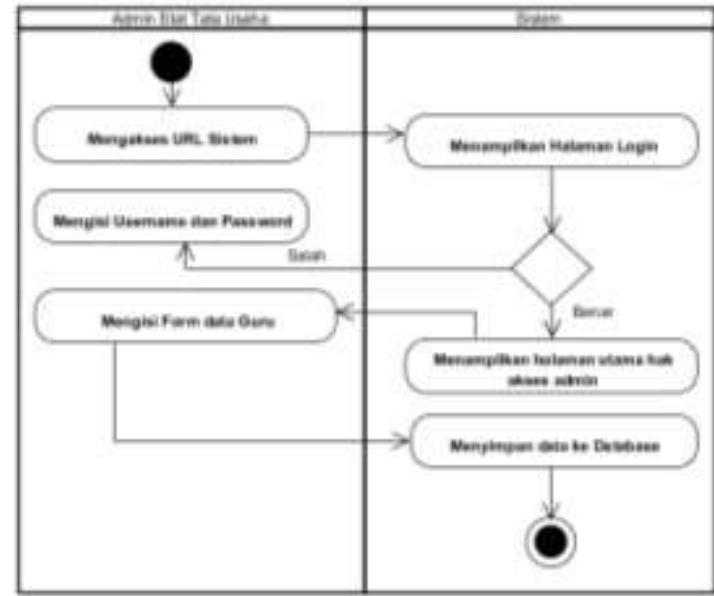

Gambar 3.3. Activity Diagram Input Data Guru 2). Input Data Siswa

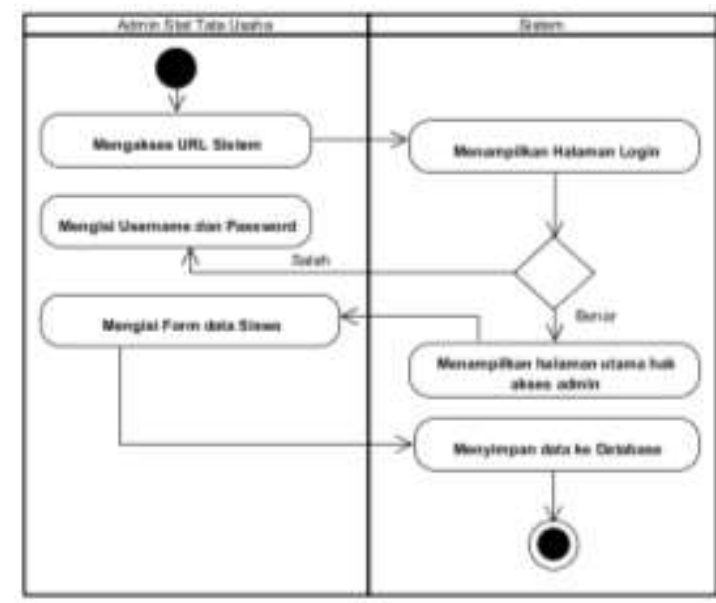

Gambar 3.4. Activity Diagram Input Data Siswa 3). Input Jadwal

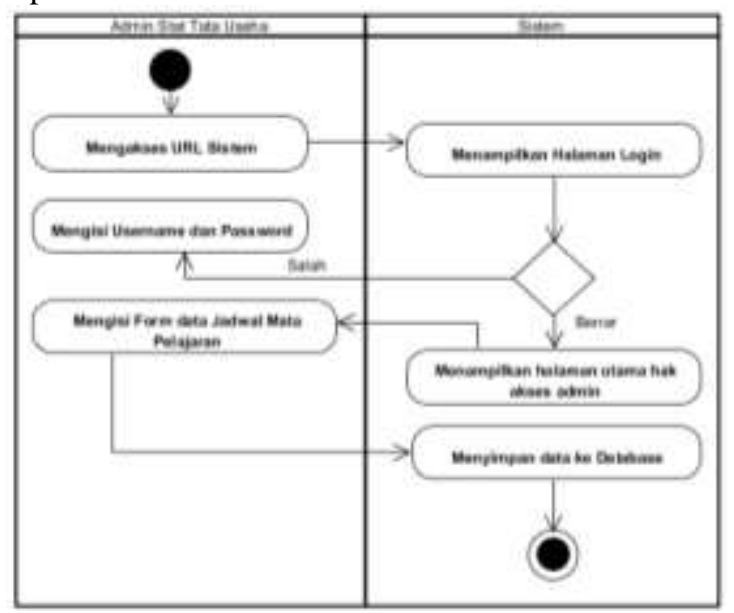

Gambar 3.5. Activity Diagram Input Jadwal 4). Input Data Kelas 
Universitas AL Asyariah Mandar

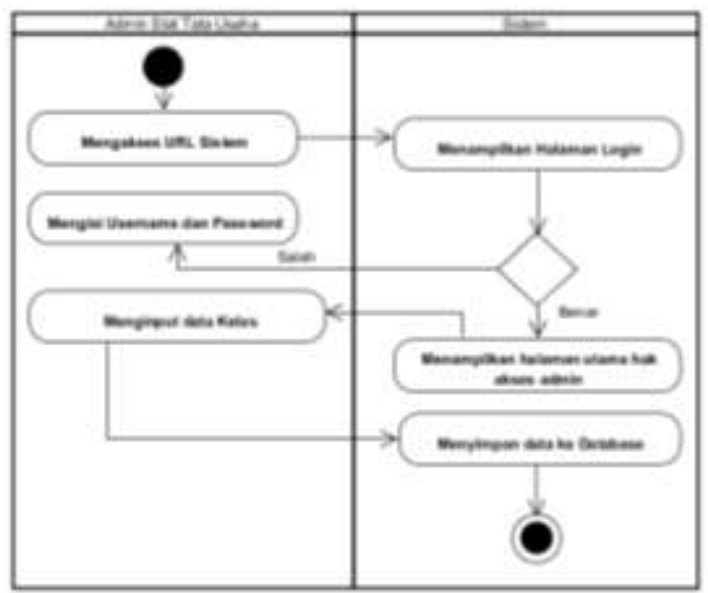

Gambar 3.6. Activity Diagram Input Data Kelas 5). Input Mata Pelajaran

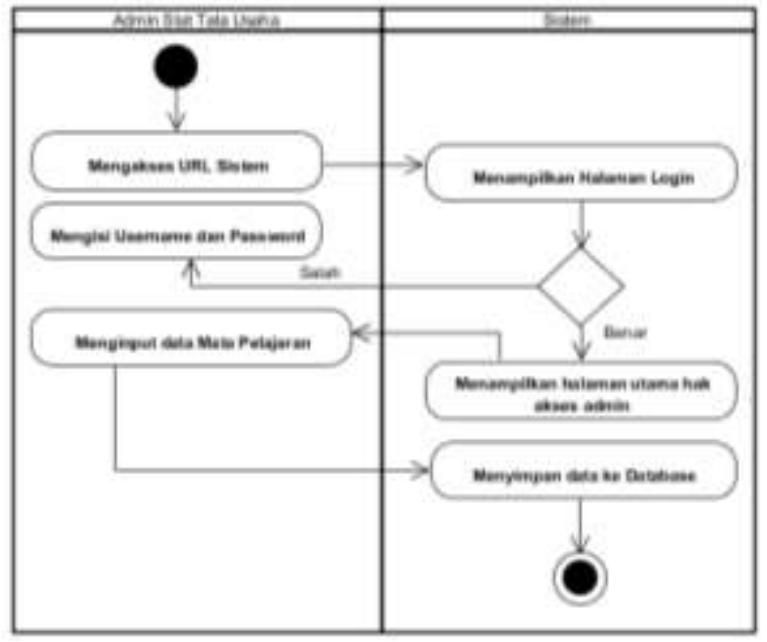

Gambar 3.7. Activity Diagram Input Data Mata Pelajaran

6). Mengabsen Siswa oleh Guru

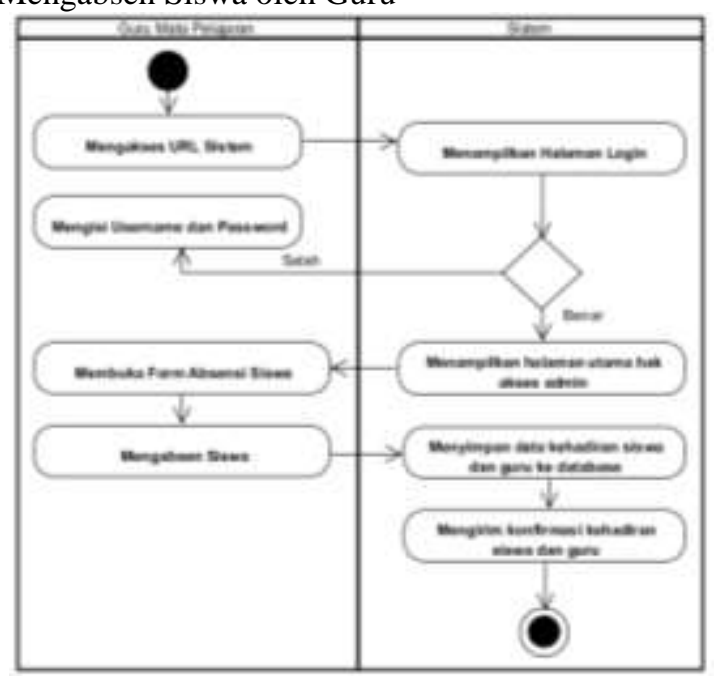

Gambar 3.8. Activity Diagram mengabsen siswa 7). Mencetak kehadiran siswa oleh wali kelas

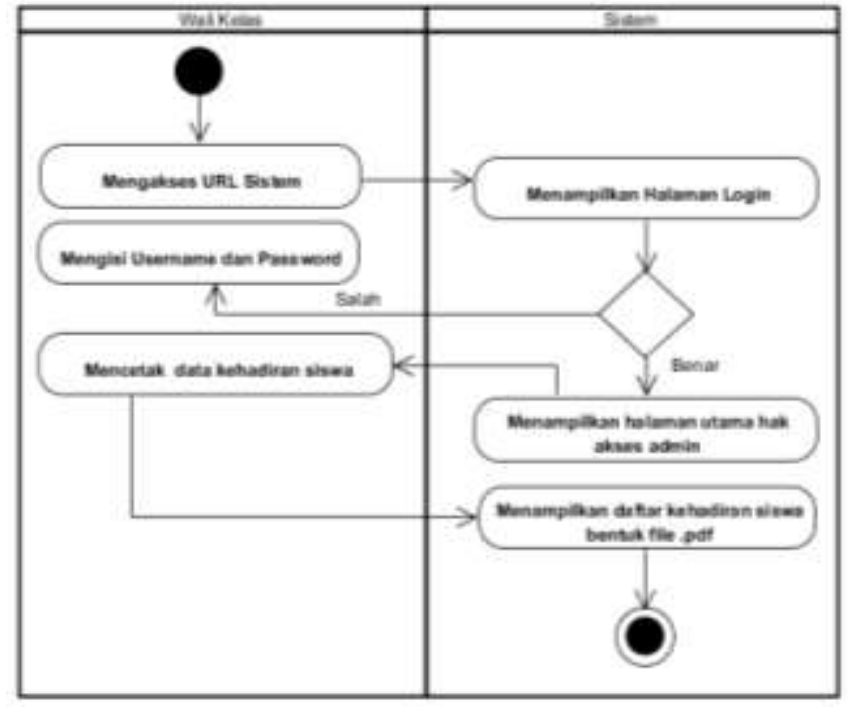

Gambar 3.9. Activity Diagram mencetak kehadiran siswa

b. Sequence Diagram

1). Input Data Siswa

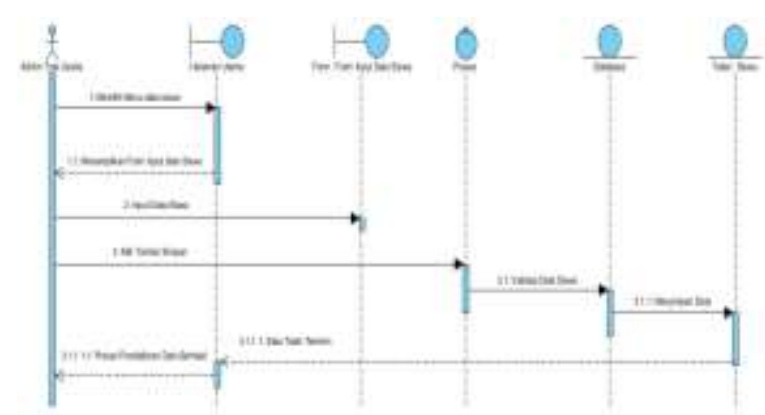

Gambar 3.10. Input Data Siswa

2). Input Data Guru

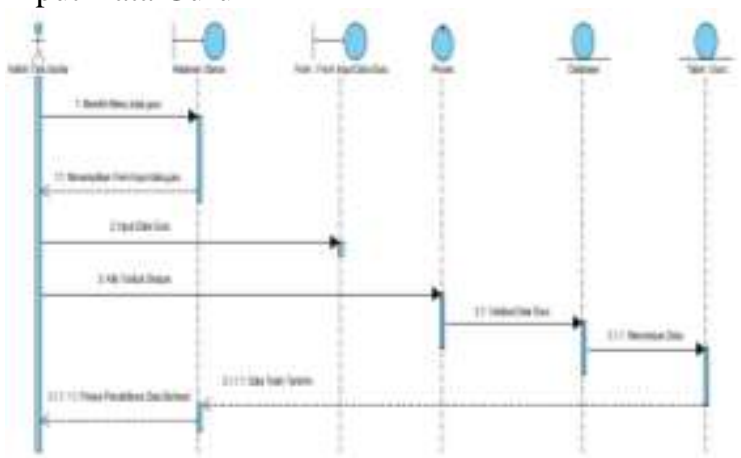

Gambar 3.11. Input Data Guru

3). Input Mata Pelajaran

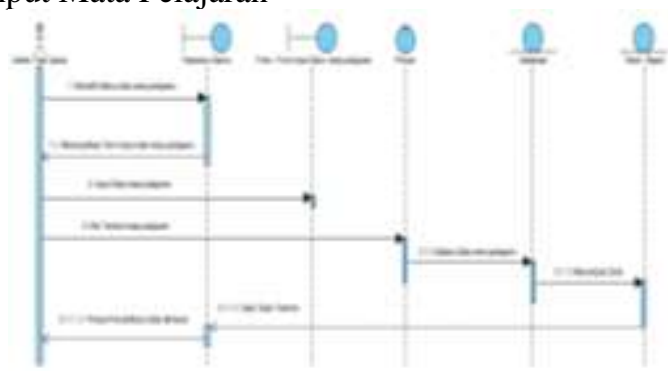

Gambar 3.12. Input Data Mata Pelajaran 
4). Input Jadwal

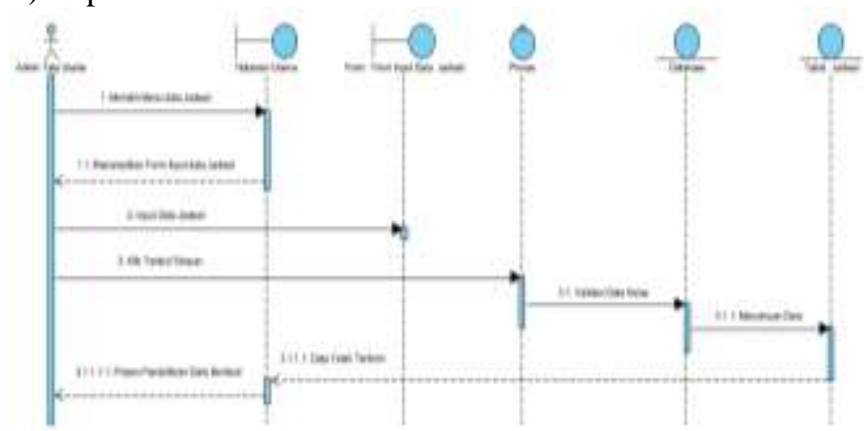

Gambar 3.13. Input Data Jadwal

5). Cetak Laporan Kehadiran Guru

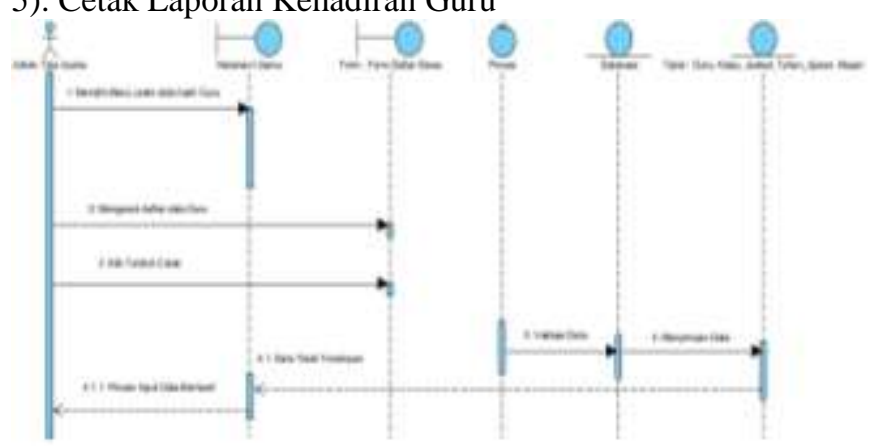

Gambar 3.14. Cetak kehadiran laporan guru

6). Mengabsen siswa

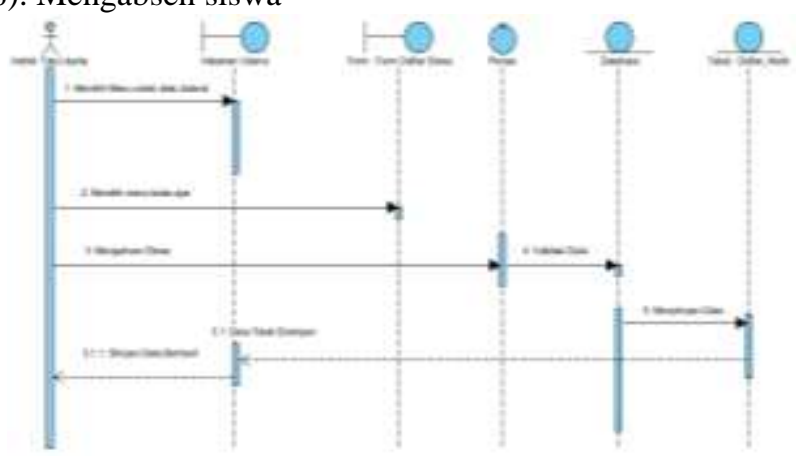

Gambar 3.15. Mengabsen Siswa

c. Class Diagram



Gambar 3.16. Class Diagram Sistem cerdas monitoring kehadiran guru dan siswa dengan aplikasi telegram berbasis web responsive pada SMP Negeri 16 Bulukumba

\section{HASIL PENELITIAN}

Dari beberapa tahapan yang telah dilakukan dalam pembangunan sistem cerdas monitoring kehadiran guru dan siswa dengan aplikasi telegram berbasis web responsive pada SMP Negeri 16 Bulukumba, maka penelitian ini menghasilkan sistem sebagai berikut :

\subsection{Form Login}

Untuk dapat mengakses sistem ini, maka semua pengguna dapat melakukan login seperti staft tata usaha, wali kelas, kepala sekolah dan guru BK. Setiap actor mempunyak hak akses masing-masing dengan akun yang sudah diberikan. Form login terlihat seperti pada gambar 4.1.

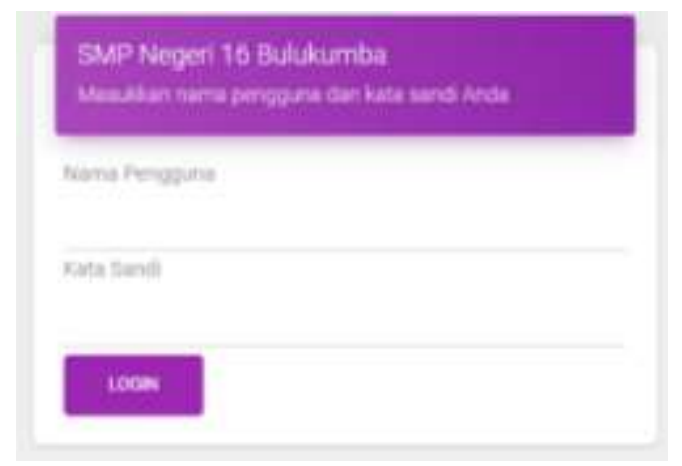

Gambar 4.1. Form Login

\subsection{Halaman Dasboard}

Setelah melakukan login dan berhasil, maka akan terbuka halaman dashboard seperti pada gambar 4.2.

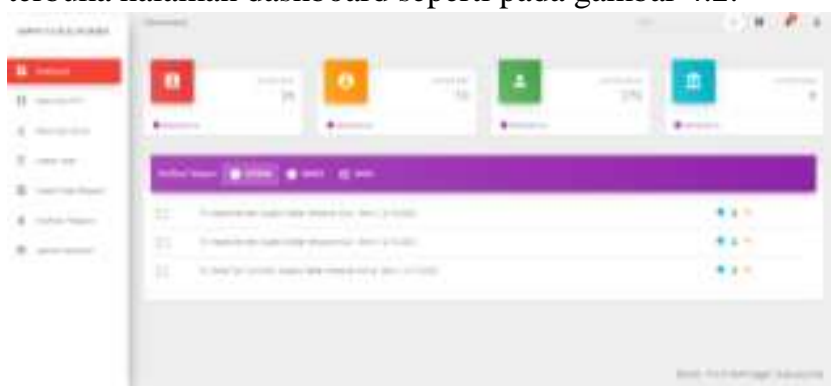

Gambar 4.2. Halaman Dasboard

\subsection{Form Mengolah Data Guru}

Form olah data guru berfungsi untuk mengelola data guru dan tenaga kependidikan seperti menambah data, menghapus dan mengedit data, seperti pada gambar 4.3.

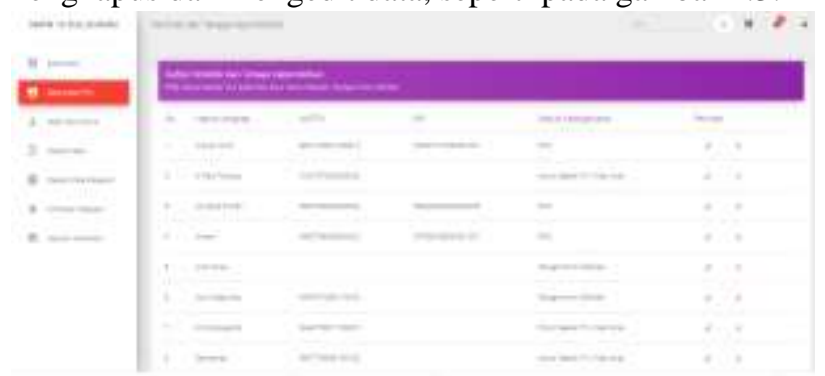

Gambar 4.3. Form Mengolah Data Guru

4.4. Form Mengolah Data Siswa 
Universitas AL Asyariah Mandar

Form olah data siswa berfungsi untuk mengelola data siswa seperti menambah data, menghapus dan mengedit data, seperti pada gambar 4.4.

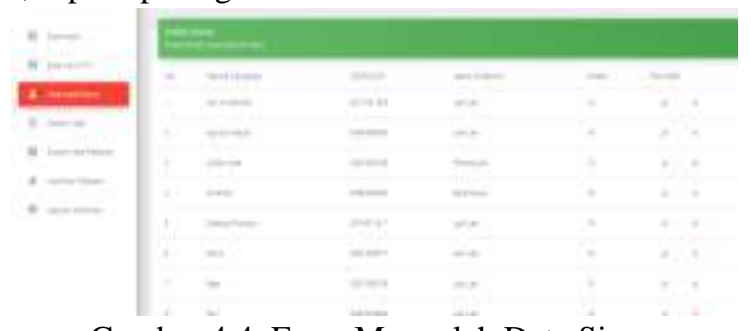

Gambar 4.4. Form Mengolah Data Siswa

\subsection{Form Mengolah Data Mata Pelajaran}

Form olah data mata pelajaran berfungsi untuk mengelola data mata pelajaran seperti menambah data, menghapus dan mengedit data, seperti pada gambar 4.4.

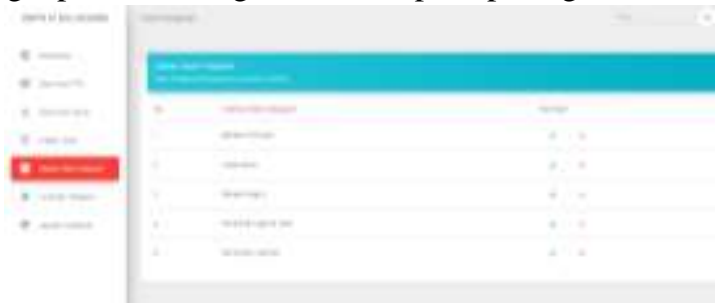

Gambar 4.5. Form Mengolah Data Siswa

\subsection{Form Cetak Laporan Kehadiran Guru dan Siswa}

Pada form cetak lapran kehadiran guru dan siswa dapat dilakukan dengan cara memilih jenis cetak laporan apakah guru dan siswa, selanjutnya memilih tanggal cetak laporannya, seperti terlihat pada gambar 4.6.

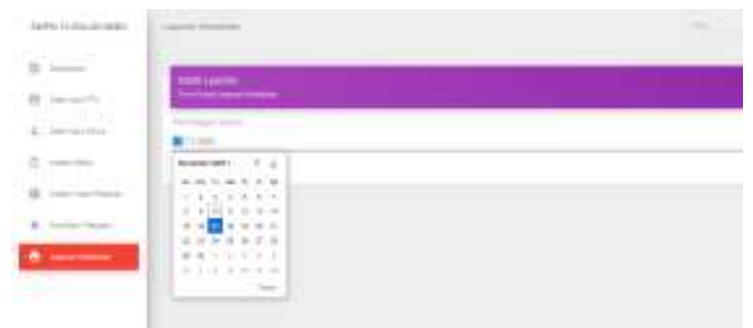

Gambar 4.6. Form Cetak Laporan Kehadiran Guru dan Siswa

\subsection{Notifikasi Kehadiran Guru dan Siswa}

Untuk notifikasi kehadiran guru akan terkirim ke kepala sekolah dan notifikasi kehadiran siswa akan terkirim ke orang tua siswa sesuai dengan data nomor telpon orang tua yang ada di data siswa dengan menggunakan aplikasi telegram. Notifikasi kehadiran akan terkirim apabila guru melakukan absensi siswa (mengabsen siswa), maka secara otormatis sistem akan mengirim notifikasi kehadiran guru bahwa guru tersebut hadir, begitu pula dengan informasi kehadiran akan terkirim ke orang tua siswa jika guru telah menyimpan data absensi tersebut pada setiap pertemuan.

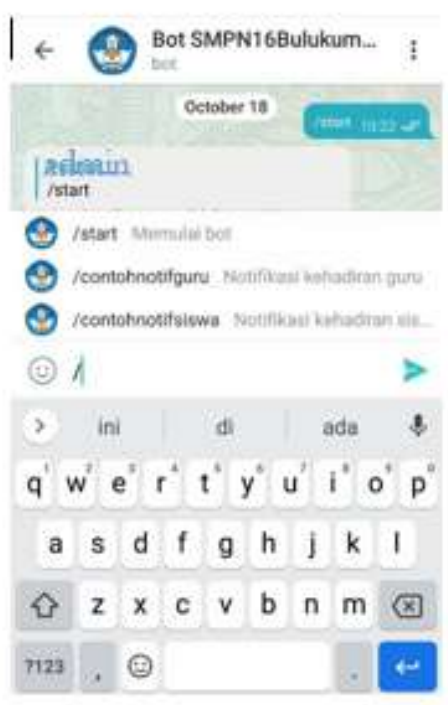

Gambar 4.7. Notifikasi Pengiriman Kehadiran Guru dan Siswa

4.8.Laporan notifikasi pengiriman kehadiran guru dan siswa

Apabila guru telah mengabsen siswa maka notifikasi akan terkirim, baik kepada kepala sekolah untuk kehadiran guru dan kepada orang tua siswa untuk kehadiran siswa. Laporan nofikasi kehadiran yang telah terkirim dapat diliat oleh admin dalam hal ini adalah staft tata usaha, seperti terlihat pada gambar 4.7.



Gambar 4.8. Laporan Notifikasi Pengiriman Kehadiran Guru dan Siswa

\section{KESIMPULAN}

1. Dalam membangun sistem cerdas monitoring kehadiran guru dan siswa dengan aplikasi telegram pada SMP Negeri 16 bulukumba dibangun dengan menggunakan model pengembangan Rapid Application Depelopment (RAD) dengan tools perangcangan UML dan bahasa pemrograman $\mathrm{PhP}$ dan HTML serta database mysql

2. Sistem Cerdas Monitoring kehadiran guru dan siswa dengan aplikasi telegram berbasis web responsive pada SMP Negeri 5 Bulukumba diimplementasikan dengan baik dengan hasil pengujian kelayakan sistem mencapai $93 \%$.

\section{Daftar Pustaka}

[1] Akbar, dkk. 2017. Rancangan Sistem Evaluasi dan Monitoring proses Pembelajaran Pada Program Studi. Universitas Stikubank. 
Universitas AL Asyariah Mandar

[2] Ericson, \& Effiyaldi. (2018). Analisis dan Perancangan Sistem Informasi Administrasi Disposisi Surat Berbasis Web Pada Dinas Pekerjaan Umum dan Perumahan Rakyat Provinsi Jambi.

[3] Hendini, A. (2016). Pemodelan UML Sistem Informasi Monitoring Penjualan dan Stok Barang (Studi Kasus : Distro Zhezha Pontianak). Khatulistiwa Informatika, 108-111.

[4] Irawan, A., M, M. A., \& Elyas, A. (2017). Perancangan Sistem Informasi Penjualan Pakaian Pada CV NONNINTH INC Berbasis Online. Positif, 76.

[5] Kadir, Abd. 2014. Pengenalan Sistem Informasi Edisi Revisi. Yogyakarta : ANDI.

[6] Kendall, J.E. \& Kendall, K.E. 2010. Analisis dan Perancangan Sistem. Jakarta : Indeks.

[7] Kuswara Heri \& Kusmana Deni. 2017. Sistem Informasi Absensi Siswa Berbasis Web Dengan SMS Gateway Pada Sekolah Menengah Kejuruan. Vol. 6 No.2. AMIK BSI Jakarta.

[8] Mustari Fachrival. 2018. Aplikasi Absensi Guru Pada Sekolah Berbasis Android (Study Kasus SMP Negeri 1 Bulukumba. UIN ALAUDDIN. Makassar.

[9] Novita, dkk. 2017. Aplikasi Monitoring Proses Belajar Mengajar Berbasis Web di SMK Telkom Bandung.

[10] Putra, D. W., \& Andriani, R. (2019). Unified Modelling Language (UML) dalam Perancangan Sistem Informasi Permohonan Pembayaran Restitusi SPPD. Teknoif, 33

[11] Sagala Raphita Jijon, 2018. Model Rapid Application Development (Rad) Dalam Pengembangan Sistem Informasi Penjadwalan Belajar Mengajar. Vol. 2 No. 1, STMIK Pelita Nusantara Medan.

[12] Sukrianto Darmanta \& Agustina ST. 2018. Pemanfaatan SMS Gateway Pada Sistem Informasi Absensi Siswa di SMAN 12 Pekanbaru Berbasis Web. Vol. 2 No. 2. AMIK MAHA PUTRA RIAU.

[13] https://www.brilio.net/gadget/10-keunggulantelegram-dibandingkan-whatsapp-yang-jarangorang-tahu-1605055.html\#. Tanggal Akses : 19 Agustus 2019 Pukul 21.16 Wita. 